\title{
ФОРМИРОВАНИЕ ПСИХОСОЦИАЛЬНЫХ КАЧЕСТВ У ШКОЛЬНИЦ ГИМНАЗИЧЕСКОГО ЦИКЛА В СИСТЕМЕ ТРЕНИРОВОЧНЫХ ЗАНЯТИЙ ИГРЫ «ВОЛЕЙБОЛ»
}

\author{
Ясыбаш П. А. \\ преподаватель физической культуры \\ гимназия А. Пушкин
}

\begin{abstract}
Аннотация: Благодаря относительно постоянному контингенту занимающихся, увеличению объема времени, выделенного на двигательную активность, возможности осуществления индивидуального подхода со стороны педагога и многих других преимуществ, секционные занятия способны создать благоприятные условия для формирования психосоциальных и физических качеств у школьниц гимназического цикла. Открытие секции по виду спорта всегда определяется наличием детей, желающих посещать занятия в силу имеющихся у них определенных мотивов и потребностей. В связи с чем, набор в секцию производится на добровольной основе. Сохранение же численности группы будет зависеть от соответствия предложенных методов, средств и педагогических подходов желаниям занимающихся. Так, традиционно у девочек-подростков в силу имеющих место изменений в телосложении, характере, преобладающих эмоций возникает потребность в развитии когнитивной сферы, физическом совершенствовании, познании себя, обретении друзей, а спорт рассматривается как площадка для их удовлетворения. Занятия волейболом, бесспорно, являются эффективным средством для развития физических качеств, в то время как в рамках секционных занятий необходимо создавать дополнительные условия для направленного развития когнитивных качеств, осуществления плодотворной психологической адаптации девочек подросткового возраста. Таким образом, была определена цель экспериментальной методики - формирование психосоциальных качеств у школьниц гимназического цикла в системе тренировочных занятий игры «волейбол».
\end{abstract}

Ключевые слова: психосоциальные качества школьниц, игра волейбол, тренировочные занятия.

Основная идея методики заключалась в предположении о том, чтобы посредством специально подобранных упражнений, их логичного сочетания, 
верного дозирования и постепенного усложнения возможно достижение следующего эффекта для личности девочки-подростка:

1. уменьшение уровня личностной тревожности;

2. снижение показателей агрессивности;

3. воспитание потребности в достижении успеха;

4. повышение значения психологической адаптации в коллективе;

5. образование доброжелательных отношений в группе.

6. повышение уровня внимания;

7. улучшение показателей памяти;

8. совершенствование мыслительных способностей;

9. повышение уровня успеваемости.

Осуществляя подбор наиболее эффективного способа влияния на личность девочек подросткового возраста, мы обратились к трудам известных педагогов и психологов, предлагающих различные средства формирования важных качеств личности и минимизации отрицательных свойств характера (Л.И. Божович, 1972;. Л. С. Выготский, 1984 и др.). Так, решение широкого круга педагогических задач становится возможным благодаря использованию в коллективе подростков различных психологических игр. Велика роль данных игр в психологической диагностике, что немаловажно для дальнейшего планирования и осуществления педагогических воздействий. Диагностировать можно личностные характеристики, наклонности подростков, предугадать возможные варианты поведения в самых разных жизненных ситуациях, определить степень сплоченности коллектива, способности к выполнению роли лидера и многое другое. Психологические игры обладают рядом преимуществ перед обычным тестированием в виде опроса, поскольку застают личность подростка в естественных условиях, не дают ему ориентироваться на идеальное «я» и принимать социально одобряемые решения.

Еще одна важная функция психологических игр - развивающая. При помощи данных средств становится возможным воздействие на многие личностные качества подростка, в числе которых навыки конструктивного поведения, умение работать в команде, способность быть лидером. Кроме того, психологическая игра может использоваться в качестве проблемного поля, на чьих просторах выстраиваются различные ситуации в учебе, спорте, семье. Психологические игры можно применять многократно, давая возможность участникам анализировать свое решение или поведение, корректировать их с целью совершенствования. 
Решающее значение для повышения результативности занятий в спортивной секции имеет не только высокая посещаемость, но и тесно связанное с ней разнообразие заданий, их форм проведения. Бесспорно, игра в волейбол в данном контексте всегда может предложить своим участникам непредсказуемый сюжет и финал. Однако, помимо учебной игры присутствующие в тренировочном процессе средства должны всегда удивлять занимающихся, доставлять им новые эмоции, не представлять собой механическое выполнение упражнений. Для этого игровые задания в методике должны быть разнообразны по содержанию, а по форме индивидуальные, групповые и коллективные.

Беря во внимание значение педагогических воздействий в подростковом возрасте для воспитания личности, обязательным является осуществление содействию психологической адаптации школьника в коллективе на различных уровнях, в том числе в рамках занятий спортивной секции. Задача педагога в данном случае заключается в том, чтобы в максимально короткие сроки изучить индивидуальные особенности характера своих воспитанников. Это позволит осуществлять индивидуальный подход к каждому. Наиболее эффективными являются такие средства социальной адаптации, при которых субъекты вливаются в коллектив постепенно, формируя о себе у остальных участников наиболее объективное мнение, имея возможность его коррекции. В методике представлены специальные психофизические упражнения в игровой форме, способствующие постепенной социальной адаптации подростков и традиционно применяемые в педагогике. Важным моментом является особенность последовательности данных заданий. Так, девочкам сначала предлагается выполнять задания в парах, затем в тройках и т.д. Предполагается, что данный подход помогает детям, наименее адаптированным к взаимодействию в коллективе, постепенно формировать доверие к каждому из участников группы, расширяя круг своего общения.

Помимо игровых заданий, которые являются наиболее эффективными в деле социальной адаптации, используются и другие средства. Согласно методике после первоначального тестирования выявлялись девочки, имеющие наименьший уровень социальной адаптации. Такие задания, как проведение подготовительной части занятия и судейство игры в волейбол данные подростки выполняли позже, чем те, кто имеют высокий показатель социальной адаптации. Это дает возможность убедиться в том, что ошибки могут совершать все, прийти к пониманию доступности возложенной на него миссии. 
Однако, от педагога требовалось особое внимание к каждому участнику, для чего использовались различные приемы: похвала, подбадривания, замечания, приведение различных примеров и сравнений.

Современные исследования рассматривают сюжетно-ролевые игры как эффективное средство для преодоления внутренних конфликтов, свойственных детям подросткового возраста и являющихся причиной высокого уровня тревожности (О.В. Рубцова, 2012). Так, для уменьшения показателей самооценочной и межличностной тревожности видится перспективным использование таких игровых ситуаций, в которых участники имеют возможность экспериментировать, играя различные роли. Выступая от лица предложенного героя, игрок может освободиться от черт характера, свойственных ему (стеснительность, нерешительность) и наоборот, проявить не наблюдаемые ранее качества (чувство юмора, смелость, артистизм). Далее ожидается анализ собственного поведения, принятие себя новым, понимание новых границ своих возможностей. Неуверенность в себе во время общения с окружающими - частая проблема в среде подростков. Тем не менее, такие игры, в которых приветствуется диалог и высказывание собственного мнения, способны помочь подростку получить положительный опыт самопрезентации, заставить поверить в дальнейший успех. Таким образом, в методике были представлены ролевые и диалоговые упражнения в игровой форме. Девочкам были предложены на выбор различные задания, выполнение которых требовало от них открытости, смелости, раскрепощенности. Порядок выступления определялся самими школьницами. В начале каждого занятия проходила одна презентация продолжительностью не более 5 минут.

1. «Какая я, когда..». Данное задание включало ответы на вопросы, характеризующие участницу (...когда я довольная....рустная...злая... завидую....болею....меня обидели....я руковожу...подчиняюсь....выигрываю ....проигрываю.....ленюсь.....очень хочу чего-либо).

2. «Моя проблема в том, что я ...». Задание заключалось в составлении небольшого рассказа о тех чертах своего характера, которые, по мнению автора, мешают достигнуть тех или иных целей, полноценно общаться.

3. «Хвастовство». Данный тренинг предназначен, чтобы создать условия для озвучивания черт характера, своих условий жизни, достижений, которыми можно гордиться. 
4. «Mои сильные стороны». Участнице необходимо было назвать сильные стороны своего характера и привести примеры их положительного применения в жизни: учебе, спорте, семье.

5. «Рассказ о своих страхах». Данное упражнение требует признать существование своих страхов, рассказать о них, когда и почему они возникли.

6. «Рассказ о своих комплексах». Подобно предыдущему упражнению, необходимо было озвучить имеющие место несоответствия представлений о себе и о своем идеальном «Я».

7. «Прогноз погодыl». Упражнение с заданием исполнить роль телеведущей, сообщающей о прогнозе погоды. Важно сделать это артистично, с юмором.

8. «Выпуск новостей». Задание, аналогичное «Прогнозу погоды», только от исполнителя требовалось сообщить согласно стилю о самых последних новостях. Приветствуется импровизация, юмор, артистизм.

9. «Самореклама». В рекламном жанре необходимо было создать рекламу самого себя как самого лучшего друга и коллеги.

10. «Кольбельная». По выбору исполнить любую известную колыбельную, либо собственного сочинения.

11. «Анекдот». Необходимо было рассказать коллективу смешной анекдот.

12. «Toсm». Произносился в соответствующем стиле тост на свободную тематику.

13. «Сnеть песню». Предлагалось исполнить песню, в которой слова и музыка принадлежат различным произведениям.

14. «Частушки» Необходимо было спеть частушки на тему спорта.

15. «Грустная история». Участница должна была рассказать выдуманную, либо произошедшую в реальной жизни историю с печальным сюжетом, соблюдая необходимый стиль рассказчика, сохраняя интерес слушателей.

16. «Моя мечта». Упражнение представляло собой рассказ перед группой о своей мечте, о том, что мешает ее исполнению и что необходимо сделать для ее осуществления.

17. «Bce $\mathrm{Mbl}$ похожи». Согласно условиям данной игры участникам предлагалось разбиться на пары. Общение в каждой паре заключалось в том, чтобы в процессе перечисления своих черт характера найти общие качества. Далее следует смена партнеров до тех пор, пока круг не замкнется. Учитывая 
то, что предыдущие задания носили личностный характер, последнее в цикле занятие служит итогом знакомства и объединение всех членов команды.

Высокий уровень агрессии у девочек-подростков часто проявляется вербально, эмоционально, косвенно, реже - физически. Данные дети нуждаются в преодолении подобных трудностей. Основываясь на концептуальных исследованиях, можно предположить, что направленное воздействие на личность с целью снижения уровня агрессивности должно осуществляться через эмоциональную, поведенческую и когнитивную сферу. В методике предлагаются игры, в которых необходимо выразить положительные эмоции по отношению к другим, найти компромисс в конфликтной ситуации, проявлять заботу о товарищах: выручить, взаимодействовать в паре. В таких ситуациях возможно создание условий для возникновения чувств сострадания и сопереживания. Также можно предположить, например, что игры без определения победителя не вызывают чувства соперничества, не противопоставляют игроков друг другу, не сравнивают их, что, в свою очередь, также благоприятно с точки зрения минимизации агрессии в поведении девочек подросткового возраста. С этой целью в методику были включены игры без определения победителя, с выручкой и т.д.

1. «Салки-выручалки». Подвижная игра, по условиям которой водящий должен был осалить других участников. Участники могли выручать осаленных игроков, дотрагиваясь до них рукой. Игра способствует воспитанию смелости и самоотверженности, учит сопереживанию.

2. «Комплементы с большим мячом». Участники выстраивались в круг и передавали друг другу большой резиновый мяч. Вместе с передачей необходимо было сделать комплемент тому, кто принимает мяч. Игра способствует проявлению положительных эмоций, учит находить хорошие качества.

3. «Встреча на узком мостике». Для выполнения данного упражнения игроки разбиваются по парам. Необходимо пройти по проведенной на полу линии (скамейке) в противоположном друг другу направлении, стараясь достигнуть конца моста как можно быстрее. Ведущий давал установку на стратегию поведения:

- договориться о том, как пройти мост;

- не уступать друг другу ни в коем случае,

- один уступает, чтобы избежать столкновения. 
Далее следует обсуждение результатов тренинга (кто остался в выигрыше, какое решение оказалось наиболее эффективным, какие эмоции испытывают люди в подобных ситуациях). Упражнение учит вести себя в конфликтных ситуациях, иллюстрирует отрицательную сторону агрессивного поведения.

\section{Список литературы}

1. БОЖОВИЧ, Л.И. Изучение мотивации поведения детей и подростков. M. 1972.

2. БОЖОВИЧ, Л.И. Проблемы формирования личности. - М., 1995. - С. 213-227.

3. ВАЙНБАУМ Я.С. Физические упражнения и здоровье школьников / Физическая культура в школе, 2010 - 64 с.

4. ВАЙЦЕХОВСКИЙ С.М. Книга тренера. - М.: Физкультура и спорт, 1971. $312 \mathrm{c}$.

5. ВАНЮХИНА, Н.В. Особенности психических состояний детей подросткового возраста: дис. .канд. псих. наук. -Казань., 2004.-215с.

6. ВДОВИНА, О.С. Влияние спортивных игр на формирование личностных особенностей студентов, занимающихся различными видами спорта // Молодой ученый. - 2015. - №11. - С. 584-587. - URL https://moluch.ru/archive/91/19781/ (дата обращения: 09.03.2019).

7. ВЕГУНОВА, А.А. Взаимосвязь коммуникативных способностей и мотивации достижения подростков// Ананьевские чтения - 2016: Психология: вчера, сегодня. 